\title{
Nablonium is a congener of Ammobium (Asteraceae-Gnaphalieae)
}

\author{
Arne A. Anderberg
}

\begin{abstract}
Anderberg, Arne A. (Swedish Museum of Natural History, Department of Phanerogamic Botany, P.O. Box 50007, S-104 05 Stockholm, Sweden) 1990. Nablonium is a congener of Ammobium (AsteraceaeGnaphalieae). Telopea 4(1):129-135. The monotypic genus Nablonium Cass. is demonstrated to be a taxon with its closest extant relative within the genus Ammobium R.Br. Thus, N. calyceroides is transferred to the latter genus, and the new combination Ammobium calyceroides (Cass.) A. Anderb. is made. The phytogeography and systematic position of the genus is briefly discussed.
\end{abstract}

\section{Introduction}

The genus Ammobium R.Br., or at least one of its species, viz. A. alatum R.Br., is well known to everyone familiar with Australian Asteraceae, but also to horticulturists who know of it as the 'winged everlasting'. Ammobium alatum is not uncommon in dry forests and on forest edges in north-eastern New South Wales and south-eastern Queensland. In Tasmania and South Australia it occurs only as a garden escape (Curtis 1963, Cooke 1986). Reaching one metre in height and having distinctly winged stems, showy white involucral bracts and yellow florets, this is a conspicuous plant which easily attracts attention in the field. The second species of the genus, $A$. craspedioides, is confined to meadows and forest edges near Yass (N.S.W.). At first glance it has an extraordinary superficial similarity to a much more common taxon of another genus, i.e. Craspedia glauca. Due to apparent similarity it is possible to $A$. craspedioides has been overlooked, but I suspect it to be a very rare and possibly endangered species. During my Australian field trip with B. Nordenstam towards the end of 1989, I was fortunate enough to find not only $A$. alatum but also the rare $A$. craspedioides in the field.

The monotypic genus Nablonium Cass., confined to Tasmania and to the islands of Bass Strait, is a $5 \mathrm{~cm}$ high, stoloniferous perennial which has long been a taxonomic problem, because of its aberrant morphology.

In the present paper it is argued that the three superficially dissimilar plants mentioned above have common ancestry and form a monophyletic group. The reasons are presented below.

\section{Earlier work}

The systematic position of Ammobium has never been controversial. Brown (1824) indicated that the genus belonged to the same tribe as Gnaphalium L., which is still a valid statement (i.e. the Gnaphalieae sensu Anderberg 1989). Merxmüller et al. (1977) included Ammobium in what they called the 'Helichrysum group' of the Inuleae-Gnaphaliinae. Orchard (1981), discussing Ixodia, Cassinia, Ozothamnus and other genera, stated that Ammobium was probably a relative of this generic group.

Nablonium Cass., originally placed in the tribe Anthemideae by Cassini (1825) due to 
some alleged similarity with Cotula and other genera of that tribe, was later (Bentham 1867) placed in the tribe Heliantheae. Still later, Bentham (1873) changed its position from the Heliantheae to the Inuleae. Hoffmann (1890), following Bentham (1873), placed Nablonium in the Inuleae-Buphthalmineae, a group comprising various genera with paleate receptacles, which are today considered to belong to several different tribes.

Leins (1971) investigated the pollen ultrastructure of the Inuleae-Inulinae and the Inuleae-Buphthalminae. Because of Hoffmann's circumscription of the InuleaeBuphthalminae, Nablonium was also investigated in this context. The pollen of virtually all investigated taxa had only one sexine layer, whereas pollen of $N$. calyceroides was completely different. With a double sexine having a perforated inner layer, the pollen morphology of Nablonium approached the pollen structures described for members of the Inuleae-Gnaphaliinae, Inuleae-Angianthiinae, and the Inuleae-Anthrixiinae (Besold 1971). Leins concluded that Nablonium was misplaced in the Inuleae-Buphthalminae, advocating its transfer to the subtribe Angianthiinae. The only obstacle would, according to Leins, be the fact that the members of the Angianthiinae are all provided with secondary capitula. Hence, Leins hypothesized the paleate capitula of Nablonium to be an extremely reduced cluster of capitula, homologous to the secondary heads of the other Angianthiinae. He also interpreted the protruding spines and broad cypsela in Nablonium as resulting from a fusion between the cypsela itself with two surrounding involucral bracts found in many taxa of that subtribe. Merxmüller et al. (1977) accepted Lein's conjecture and placed Nablonium in the Angianthus group of the Inuleae-Gnaphaliinae s. lat.

\section{The systematic position}

In my analysis of the phylogeny of the Gnaphalieae (Anderberg in press), Nablonium was omitted as being very derived, or even misplaced in the tribe (cf. Anderberg 1989). The extent of autapomorphic character states encountered in Nablonium made it difficult to compare with other taxa. Leins' conclusion that Nablonium was a derived relative of Angianthus and the other genera of the Angianthiinae s. str. could not be corroborated in my investigation. The closest relative of Nablonium was to be found elsewhere.

I had little suspected that Ammobium alatum and Nablonium calyceroides could be closely related, until I investigated material of the second species of Ammobium, the rare $A$. craspedioides. This species proved to be almost intermediate between the other two, sharing some character states with $A$. alatum and others with $N$. calyceroides. In my analysis of the phylogeny of the tribe, Ammobium was included among the taxa of the Cassiniinae, and found to be a distant relative of the Cassinia clade itself.

\section{The characters}

1. Both species of Ammobium as well as Nablonium calyceroides are perennial herbs. The outgroup like most other genera of the Cassinia generic group are shrubs.

(0) Frutescent.

(1) Herbaceous.

2. The frutescent taxa of the outgroup are all much branched. A. alatum has an almost unbranched main stem but still a few branches in the synflorescence. A. craspedioides and Nablonium are completely unbranched. 
(0) Stems branched, at least apically.

(1) Stems unbranched.

3. The lower surface of the leaves are clad with whitish tomentum in all taxa. The leaves are strongly decurrent in $A$. alatum, forming broad stem wings. In $A$. craspedioides the cauline leaves are somewhat decurrent basally, something which cannot be detected in Nablonium. The outgroup includes taxa with or without decurrent leaves and has consequently been coded with a question-mark in the matrix.

(0) Leaves at least somewhat decurrent.

(1) Leaves not decurrent.

4. The leaves in all taxa form a basal rosette. In Nablonium and in A. craspedioides the short stem makes the basal leaf rosette very prominent, but in $A$. alatum it is less conspicuous. The frutescent taxa of the related genera lack basal leaf rosettes.

(0) Leaf rosette absent.

(1) Leaf rosette present.

5. The capitula are solitary in Nablonium and in A. craspedioides, but in A. alatum they are situated a few together in loose corymbs. In the outgroup and in most of the related genera the capitula are numerous and densely clustered.

(0) Capitula many together, clustered.

(1) Capitula few together, in loose corymbs.

(2) Capitula solitary.

6. The involucral bracts are tawny and transparent in both Nablonium and A. craspedioides, whereas the bracts in $A$. alatum are white and opaque. In the outgroup most taxa have white, opaque bracts, but tawny, transparent bracts are found also in some taxa. Hence, this character has been coded with a question-mark in the outgroup.

(0) Involucral bracts white, opaque.

(1) Bracts tawny, more or less transparent.

7. The paleae are apically entire in Cassinia and in the other paleate taxa of the group. Generally they are similar to the innermost bracts. Lacerate paleae are found in A. craspedioides and in Nablonium.

(0) Paleae entire.

(1) Paleae lacerate.

8. The colour of the hermaphroditic disc-florets is bright yellow in both species of Ammobium, but white in Nablonium which, however, has pale yellowish buds. The same condition can be observed in Cassinia and Ozothamnus R. Br., as well as in the related and likewise white-flowered genus Ixodia $\mathrm{R}$. Br. The outgroup has been coded with a question-mark since some species are yellow-flowered and others are whiteflowered.

(0) Florets yellow.

(1) Florets white.

9. The cypselas are glabrous and dorsiventrally more or less flattened in all three taxa. In $A$. alatum the cypsela is elongated with parallel margins, but in the other two it is stout with margins converging towards the carpopodium. The cypselas of the outgroup are small and more or less elongated. 
(0) Cypselas elongated.

(1) Cypselas stout.

10. Pappus bristles are missing, but the cypselas are provided with two apical spines derived from the apical portion of the cypsela wall. The cypselas of $A$. alatum have an apical cup-shaped outgrowth from the cypsela wall, laterally furnished with two short subulate teeth. In A. craspedioides, the apical cup is even more prominent and the two lateral teeth are larger and very protruding, looking more like lateral spines. The spines reach an even more impressive development in Nablonium, in which the cup-shaped apical portion has become an integral part of the widened apical portion of the cypsela. This is a most striking transformation series that becomes obvious when the cypselas of the three taxa are compared (Figure 1).

(0) Cypselas without spines.

(1) Cypselas with short spines.

(2) Cypselas with moderate spines.

(3) Cypselas with long spines.

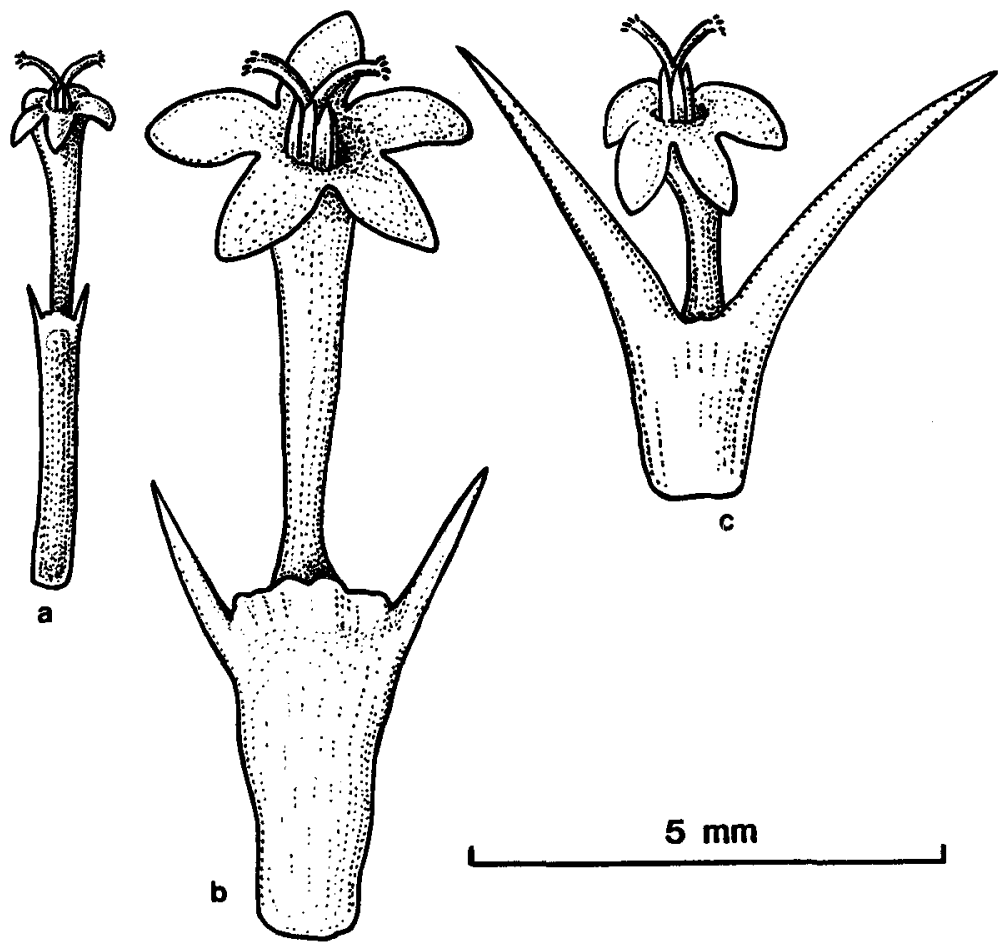

Figure 1. Cypsela and floret. a. Ammobium alatum. b. A. craspedioides. c. A. calyceroides a. Anderberg \& Anderberg 7148 (S). b. Nordenstam \& Anderberg 743 (S). c. Comber 2135 (K). 
Table 1. Data matrix. The numbers correspond to the numbers in the text and in the cladogram in figure 2 .

\begin{tabular}{lr} 
& 0000000001 \\
Cassinia & 1234567890 \\
A. alatum & $00 ? 00 ? 0 ? 00$ \\
A. craspedioides & 1001100001 \\
A. calyceroides & 1101211012 \\
\hline
\end{tabular}

\section{Cladistic analysis}

In order to elucidate the phylogeny of Ammobium alatum. A. craspedioides, and Nablonium calyceroides, a character data matrix (Table 1 ) was analysed with the computerised parsimony program Hennig86 (Farris 1988). The likewise paleate, and closely related, genus Cassinia was used as outgroup to analyse the interrelationships between the three taxa. The cypsela spine character (character 2) was coded as an additive transformation series, and using the option ie (implicit enumeration) only one cladogram was obtained. This cladogram was 13 steps long with a consistency index (ci) of 1 and retention index (ri) of 1 .

The most parsimonious solution to the character distribution indicates that Ammobium craspedioides and Nablonium calyceroides are sister taxa, evolved from a common ancestor. The sister taxon of this species pair is $A$. alatum. No character was found to indicate

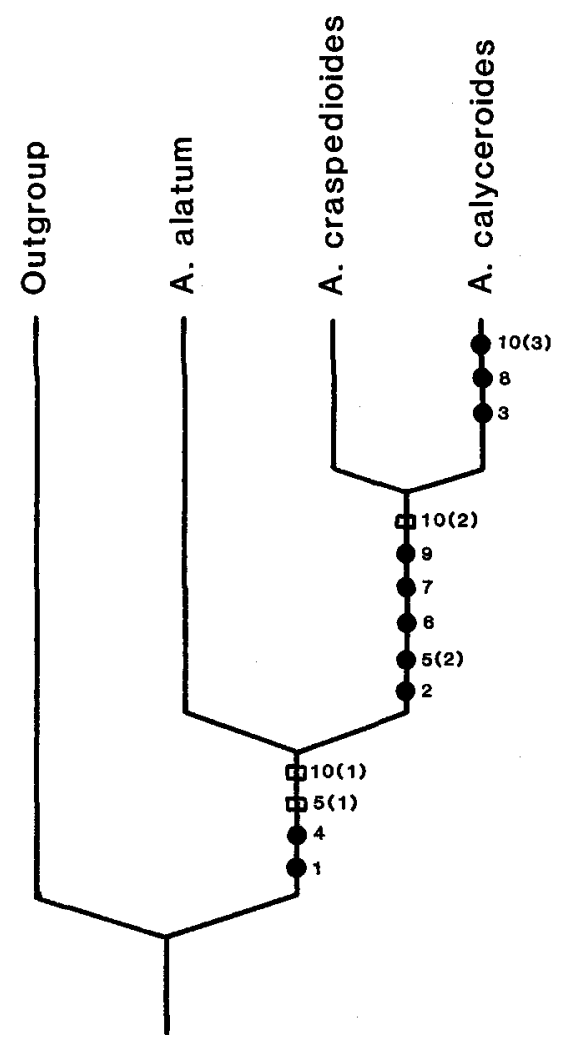

Figure 2. Cladogram of the genus Ammobium. Black dots are synapomorphies, open squares are synapomorphies transforming on the cladogram. 
that $A$. alatum and $A$. craspedioides form a monophyletic group. Ammobium is obviously paraphyletic as it stands, since $A$. craspedioides and Nablonium form a monophyletic group diagnosed by 6 synapomorphies.

Three solutions are available in order to have the taxonomy reflect the phylogeny of the group. Ammobium becomes monophyletic if Nablonium is included. It becomes monophyletic also if $A$. craspedioides is transferred to Nablonium, or if $A$. craspedioides is placed in a new monotypic genus since Ammobium will then become monotypic.

Since the three taxa together represent an evident group which would be concealed if they were to be kept as separate genera, I have chosen to include Nablonium calyceroides in Ammobium. The following new combination is thus necessary:

Ammobium calyceroides (Cass.) A. Anderb. comb. nov.

BASIONYM: Nablonium calyceroides Cassini, Dictionnaire des sciences naturelles 34: 101 (1825).

\section{Phytogeography}

The distribution of the three species of Ammobium shows a vicariance pattern that is of interest. $A$. alatum, the sister group of the other two species, has a distribution in north-eastern N.S.W. and south-eastern Queensland, whereas A. craspedioides and A. calyceroides are distributed more to the south, $A$. craspedioides occurring in N.S.W., just north of the A.C.T., and A. calyceroides in Tasmania and adjacent islands. The ancestral populations of the three taxa can be hypothesized to have undergone a successive splitting. First a north-eastern population, later evolving into $A$. alatum, was separated from a southern population (the ancestor of $A$. craspedioides and $A$. calyceroides). This southern population was later split in a continental population ( $A$. craspedioides) and a Tasmanian population (A. calyceroides).

Tasmanian-mainland vicariance patterns are found also in other genera of flowering plants. In the Gnaphalieae the genus Ewartia Beauverd has a similar distribution.

\section{Acknowledgements}

I would like to express my gratitude to my Australian colleagues for all their assistance during my field trip in Australia September to December 1989.

\section{References}

Anderberg, A.A. (1989) Phylogeny and reclassification of the tribe Inuleae (Asteraceae). Canad. J. Bot. 67: 2277-2296.

Anderberg, A.A. (in press) Phylogeny and taxonomy of the tribe Gnaphalieae (Asteraceae). Opera Bot.

Bentham, G. (1867) Flora Australiensis vol. 3 pp. 583-584. (Lovell Reeve \& Co: London).

Bentham, G. (1873) Compositae. In Bentham, G. \& Hooker, J.D., Genera plantarum vol. 2 pp. 163-533 (Lovell Reeve \& Co: London).

Besold, B. (1971) Pollenmorphologische Untersuchungen an Inuleen (Angianthinae, Relhaninae, Arthrixiinae). Diss. Bot. 14. Lehre.

Brown, R. (1824) Ammobium alatum. In Sims, J. (ed.) Curtis's Bot. Mag. vol. 51 (9), t. 2459 (Sherwood, Jones \& Co: London). 
Cassini, H. (1825) Nablonion. In Cuvier, G. (ed.) Dictionnaire des sciences naturelles vol. 34, pp. 101-103 (Le Normant: Paris).

Cooke, D.A. (1986) Ammobium. In Jessop, J.P. \& Toelken, H.R. Flora of South Australia vol. 3, p. 1495 (S.A. Govt Printing Div.: Adelaide).

Curtis, W.M. (1963) The student's flora of Tasmania vol. 2, p. 343 (Govt Printer: Tasmania).

Farris, J.S. (1988) Hennig 86, version 1.5., users reference. (Published by the author: New York).

Hoffmann, O. (1890) Compositae-Inuleae. In Engler, A. \& Prantl, K. (Eds.) Die natürlichen Pfanzenfamilien vol. 4, pp. 172-210 (Engelmann: Leibzig).

Leins, P. (1971) Pollensystematische Studien an Inuleen 1. Tarchonanthinae, Plucheinae, Inulinae, Buphthalminae. Bot Jahrb. Syst. 91 (1): 91-146.

Merxmüller, H., Leins, P., \& Roessler, H. (1977) Inuleae-systematic review. In Heywood, V.H., Harborne, J.B., \& Turner, B.L. (eds.), The Biology and Chemistry of the Compositae vol. 1, pp. 577-602 (Academic Press: London).

Orchard, A.E. (1981) The generic limits of Ixodia R. Br. ex Ait. (Compositae-Inuleae). Brunonia 4: 185-197.

Manuscript received 27 February 1990

Manuscript accepted 12 July 1990 